Cheshire by the repeated landslips which have occurred there. For several winters in succession large surfaces of ground have fallen in, it is supposed on account of the withdrawal of the salt from the salt-mines. The slip which occurred this winter is on the same spot where similar occurrences happened twelve months, two, and four years ago. The pit is abcut 300 yards in circumference, and about roo feet deep, and the sides are almost perpendicular. It is feared that if these subsidences continue the town itself will be threatened, and the attention of the Govern. ment has been called to them.

Mr. W. Laird Clowes, in a letter to a contemporary dated The Cottage, Pinner, Monday, Jan. 8, writes:-- "To-night, between 8. 5 and 8.30, I noticed three beautifully luminous atmospherical phenomena on the northern horizon. They all took the form of an arc of fire of between $8^{\circ}$ and $10^{\circ}$ in height, the first two happening within a minute of one another, and the last about eleven minutes after the second. There were a slight breeze and light clouds at the time." This was most probably an aurora borealis, but we have not seen any other account of it.

THस Trinity Board have established an electric light at the South Foreland lighthouse, which is situated between Dover and Deal. It was formally opened on New Year's Day by Sir Frederick Arrow, the Deputy-Master of the Trinity Board, in the place of Prince Arthur, who was prevented from being present. This lighthouse establishes a triangle of electric lights, the other two being at Dungeness and Cape Grisnez

THE accounts furnished by the Boston Advertiser from the captains and crews of the vessels of the whaling fleet lately destroyed or ice-bound in the Arctic Ocean concur in describing the presence of peculiar meteorological phenomena during the past season. The prevailing summer wind on the north-west coast of Alaska is from the north, and this works the ice off from the land and disperses it, while the north-westerly winds close it up on the shore. As the ice moves off, the ships generally work up by the land, and in that situation find whales in plenty. By the end of the season, when north-westerly winds are prevalent, the ice becomes so broken up and melted that it has ceased to be an element of danger, and the vessels are compelled to retire to the northward by heavy ice drifting along the coast from the north, and not from a threatened closing in upon the Jand. But this season the easterly winds were not so strong and constant as usual, and the ice that had gone off from shore returned in a heavy pack, so that it was impossible to get a ship through, or even to hold against it at anchor. The heavy ice-fields are all composed of fresh-water berg-ice, not floe-ice of salt. water. The bergs are not of the immense proportions seen in Greenland seas, but are solid enough to be equally dangerous, many masses being so heavy as to ground in ten falhoms of water.

ON Nov. 15 the town of Oran, the second city in the province of Salta, was destroyed by a series of earthquakes lasting nine hours. Very little life was lost, the first shocks being light. The inhabi:ants had time to flee to the open camp of Monte Video.

\section{SCIENTIFIC INTELLIGENCE FROM AMERICA*}

Advices from Lieutenant G. M. Wheeler, United States Engineers, whose movements during the past year we have had frequent occasion to chronicle, announce his arrival at Tucson about Dec. 4, with the men and animals nearly exhausted. The trip from Prescott to Camp A pache had been very severe, on account of the snow and high winds on the Colorado plateau. During their exploration one party had been sent to the San

* Communicated by the Scientific Editor of Harper's Weekly.
Francisco mountains, and made the ascent of the principal peak. These mountains consist of three prominences, grouping in the form of a crater, the north-eastern rim being wanting. The principal peak was occupied as a topographical, barometrical, and photographic station. It is believed to be nearly I, 000 feet higher than the peak usually ascended; and Lieutenant Wheeler was of the opini n that his party was the first to occupy its summit. This, however, was a mistake, as Dr. Edward Palmer, of the Smithsonian Institution, made the ascent in 1870 , and obtained a number of new species of plants and insects.-A document which has been for some years in preparation, and toward which much expectation has been directed by agriculturists, has just appeared from the Government press, nam-ly, the Report of the Commissioner of Agriculture upon the Diseases of Cattle in the United S:ates. About the middle of June, 1868. a disease broke out at Cairo, Ilinois, among a numb $r$ of Texas cattle, known as the Spanish fever, or the Texas cattle disease. In consequence of the rapid extension of this disease, very strious alarm was excited, and the services o Prof. John Gamgee, a distinguished English veterinarian, then in the Uni ed States, were secured by General Capron, the Commissioner of Agriculture, for the purpose of instituting a careful inquiry as to its cause, course, and methods of ireatmenr. The Professor immediately visited the infected districis in Illinois, and in the spring of 1869 examined that part of Texas on or near the Gulf coast, where the transportation of the native cattle begins. In this last journey he was accompanied by Prof. Ravenel, of South Carolina, a specialist among the fungi, and whose particular ob;ect was to determine what part such plants played in the infection. Dr. J. S. Billings and Dr. Curtis, of the army, were al oo asso. ciated in the inquiry, having special reference to the microscopic investigations. A second investigation by Prof, Gamgee, under the authority of the Commisioner of Agriculture, had reference to the subject of pleuro-pneumonia, in the course of which numerous microscopic observations were made by Dr. Woodward, of the Army Medical Museum. Full reports on these various subjects made by the different gentlemen are embodied in the volume referred to, which appears in quarto form, with numerous well-executed plates in chrnmo-lithography. It is also accompanied by a report by $\mathrm{Mr}$. Dodge, the statistician of the Agricultural department, upon the history of this Texas cattle disease, also known as splenic fever, in which the devastations of this peculiar native malady are traced back into the eighteenth century. This report was considered by General Capron as simply preliminary, and further investigations are indicated as important. Among those especially mentiuned are inquiries as to the best mode of arresting the contagion, and the proper way of trantportation of the cattle northward. He thinks that a general law of the United States, in the interest of public health, of an enlightened humanity, and of the cattle trade, should regulate this triffic, not only throughout the Gulf Siates, but on the great routes throughout the country.-A valuable ducument lately issued by the Surgeon-General's Office at Washington, prepared by Dr. G. A. Olis, consists of a report of surical cases irealed in the army of the United States from 1865 to $187 \mathrm{I}$, covering almost every possible variety of injury, whether by gun-shot wounds, lacerations, fractures, dislocations, amputations, \&c. The report, which is a quario of nearly 300 pages, is illustrated in the same excellent style as its predecessurs, and the woudcuts are especially norihy of all praise.Bills have been introduced both in the Senate and House of Representatives providing for the reservation of that portion of the region abuut the Yelluw Stone Lake, in which the wonderful geysers and hot syrings occur, to which we have repeatedly called the attention of our readers. The thorough expl:sation of that country made during the past season by Dr Haydin has enabled hirs to defive the lemits within which these natural features occur, and the bill is based upon a plan prepared under his direction. The area proposed to be preserved is about sixty five miles in length by fifty-five in width, and it is suggested that the reserva. tion be placed under the direction of the Secretary of the Interior, who is to be empowered to take such steps as may be required to protect the natural curiosities from injury or destruction. It is highly important that this should become a law at the present session, as the glowing accounts given by Dr Hayden will cause a great many persons to vi-it the country during the coming year, and with the natural iconoclasm of the Anglo-Saxon race, there is great danger that the wonderful water basius and furmations of sulphur and of calcareous and siliceous rocks will be knocked to pieces for the purjose of securing mementoes of a visit. 